\title{
EFEKTIFITAS PENGELOLAAN KEUANGAN DESA (STUDI KASUS DI DESA PURWODADI KECAMATAN TEGALREJO KABUPATEN MAGELANG)
}

\author{
Oleh : \\ Nuwun Priyono ${ }^{1)}$, Muhamad Wahyudi ${ }^{2)}$, Whinarko Juli Prijanto ${ }^{3)}$ \\ Universitas Tidar Magelang
}

\begin{abstract}
According to UU Number 6 of 2014 concerning Villages, villages have received sources of income from the State Budget. There is a need to research the HR in managing village finance and various other things that are obstacles. The objectives of this study are: 1) Analyzing the effectiveness of village financial management in Purwodadi Village, Tegalrejo Subdistrict, Magelang District, 2) Analyzing and reviewing village financial management mechanisms in Purwodadi Village, Tegalrejo Subdistrict, Magelang District, 3) Knowing the development of financial performance in Purwodadi Village, Tegalrejo District, Magelang and 4) Knowing the efforts made in dealing with the constraints of village financial management in Purwodadi, Tegalrejo Subdistrict, Magelang Regency. The output of this study is expected to produce texts sent to national journals and materials that can be used as enrichment of teaching materials in public sector accounting courses. The data used in this study are primary and secondary data, which will be taken through interviews, questionnaires and observations. Balance sheet report data and APBDes realization report data come from the Purwodadi Village Government, Tegalrejo Subdistrict, Magelang Regency This study uses time series data, namely data from 2015 and 2016. This study will be analyzed using descriptive statistical analysis. By looking at the effectiveness ratio of financial management and measuring village financial performance. The results showed that: 1) based on the APBDes realization report in 2015-2017 village financial management showed an average of $100 \%$ which means effective, 2) the development of village financial performance seen from the realization of the APBDes always increasing from 2015-2017, 3) Purwodadi Village's financial management mechanism includes several stages, namely: planning, implementation, administration and reporting and accountability, 4) several efforts have been made by the Purwodadi Village Government in overcoming obstacles and obstacles in managing village finances.
\end{abstract}

Keywords: Efektivitas, Pengelolaan, Keuangan Desa, APBDes

\section{PENDAHULUAAN}

Penerbitan Undang-Undang Nomor 6 Tahun 2014 tentang Desa, merupakan titik awal bagi desa untuk mendapatkan sumber-sumber pendapatan yang lebih luas lagi terutama yang berasal dari Anggaran Pendapatan Belanja Negara (APBN). Undangundang ini memberikan amanat kepada pemerintah untuk mengucurkan dana yang 
lebih besar lagi yang bersumber dari APBN. Sebelum adanya undang-undang ini desa hanya mendapatkan sumber pendapatan dari provinsi dan pemerintah daerah. Akan tetapi dengan undang-undang ini, desa mendapatkan sumber pendapatan baru yang berasal dari alokasi APBN yang dikenal dengan dana desa. Dengan adanya sumber pendapatan baru diharapkan desa dapat lebih meningkatkan pemerberdayaan masyarakat melalui program-program pembangunan desa.

Desa sebagai struktur organisasi pemerintahan tingkat bawah merupakan ujung tombak bagi pembangunan negara. Semakin baik suatu desa melaksanakan pembangunan dan memberikan pelayanan maka akan mendukung peran dan tugas pemerintah dalam memberikan pelayanan yang maksimal kepada masyarakat luas. Oleh karena itu pembinaan dan pemberdayaan desa sangat diperlukan dalam rangka membentuk desa yang dapat memberikan pelayanan dan melaksanakan programprogram pembangunan secara optimal.

Dengan tambahnya sumber-sumber pendapatan desa, menjadikan pengelolaan keuangan desa menjadi hal yang sangat substansial dan perlu mendapatkan perhatian bersama para stakeholder, baik pemerintah pusat, pemerintah derah, para praktisi keuangan daerah, kepala desa dan Badan Perwakilan desa (BPD) maupun masyarakat luas. Pengelolaan keuangan desa harus dapat diarahkan, dilaksanakan, dan dikelola dengan baik dan benar sesuai peraturan yang berlaku. Selain itu pengelolaan keuangan desa juga harus mampu mengedepankan transparansi dan akuntabilitas sehingga dapat terciptanya pengelolaan keuangan desa yang tertib, taat pada peraturan perundangundangan, efisien, efektif, dan memberikan manfaat bagi kesejahteraan masyarakat.

Desa Purwodadi terletak di Kecamatan Tegalrejo Kabupaten Magelang merupakan desa agraris yang sebagian masyarakatnya bermata pencaharian disektor pertanian, perdagangan, UMKM, dan lain-lain. Desa Purwodadi dalam melaksanakan program-program pembangunan desa juga melibatkan seluruh stakeholder yang ada. Program-program pembangunan yang ada didesa harus dapat direalisasikan. Oleh karena itu penyusunan Anggaran Pendapatan Dan Belanja Desa (APBDes) merupakan hal yang sangat penting dan merupaan bagian dari pengelolaan keuangan desa. Dalam APBDes seluruh rencana keuangan dalam satu tahun anggaran yang ada didesa tersaji secara rinci. 
Namun dalam pengelolaan keuangan desa yang ada di Desa Purwodadi tersebut menghadapi berbagai kendala seperti: keterbatasan SDM yang memadai, keterampilan dan pengetahuan pengelolaan keuangan desa yang kurang memadai serta kondisi pendapatan desa dan aset yang dikelola desa tersebut dari tahun ketahun terus mengalami peningkatan. Beberapa kendala tersebut harus dapat segera diatasi agar pengelolaan keuangan desa yang ada di Pemerintah Desa Purwodadi Kecamatan Tegalrejo Kabupaten Magelang dapat efektif.

Berdasarkan latar belakang tersebut diatas, penelitian ini mengkaji dan menganalisis lebih jauh mengenai efektifitas pengelolaan keuangan desa yang ada di Desa Purwodadi, bagaimana perkembangan kinerja keuangan desa dari tahun ketahun, bagaimana mekanisme pengelolaan keuangan desa dalam mendukung efektifitas serta berbagai upaya yang dilakukan dalam mengatasi kendala-kendala dalam mengelola keuangan desa. Keluaran dalam penelitian ini adalah artikel yang dimuat di jurnal nasional.

\section{KAJIAN TEORITIS}

\section{Pengelolaan Keuangan Desa}

Menurut Wardoyo (1980:41) Pengelolaan adalah suatu rangkaian kegiatan yang berintikan perencanaan ,pengorganisasian penggerakan dan pengawasan dalam mencapai tujuan yang telah ditetapkan sebelumnya. Sedangkan menurut Harsoyo (1977:121) pengelolaan adalah suatu istilah yang berasal dari kata "kelola" mengandung arti serangkaian usaha yang bertujuan untuk menggali dan memanfaatkan segala potensi yang dimiliki secara efektif dan efisien guna mencapai tujuan tertentu yang telah direncanakan sebelumnya.

Keuangan Desa adalah semua hak dan kewajiban Desa yang dapat dinilai dengan uang serta segala sesuatu berupa uang dan barang yang berhubungan dengan pelaksanaan hak dan kewajiban Desa. Kemudian pengertian dari pengelolaan keuangan desa adalah keseluruhan kegiatan yang meliputi perencanaan, pelaksanaan, penatausahaan, pelaporan, dan pertanggungjawaban keuangan desa (Permendagri Nomor 113 Tahun 2014).

Menurut Amerieska (2015), pengelolaan keuangan dan aset desa meliputi beberapa tahap yaitu:perencanaan, pelaksanaan, penatausahaan, pelaporan dan pertanggungjawaban . Sedangkan laporan pertanggungjawaban keuangan dan asset desa, antara lain : laporan pertanggungjawaban APBDesa, laporan pertanggungjawaban Dana Desa, laporan 
pertanggungjawaban Alokasi Dana Desa, dan laporan pertanggungjawaban Bantuan Keuangan.Pengelolaan keuangan desa mencakup: Perencanaan (penyusunan) APBDES: pendapatan dan belanja, Pengumpulan pendapatan (atau sering disebut ekstraksi) dari berbagai sumber: pendapatan asli desa, swadaya masyarakat, bantuan dari pemerintah atasan, dan lain-lain

\section{Efektifitas}

Menurut Mahmudi (2011) Efektivitas merupakan perbandingan antara hasil yang diharapkan (target) dengan hasil yang sesungguhnya dicapai. Hasil atau target yang diharapkan merupakan outcame sedangkan hasil yang dicapai merupakan output. Efektivitas membandingkan antara outcome dengan output. Fokus efektivitas adalah outcame (hasil). Suatu organisasi, program atau kegiatan dinilai efektif apabila output yang dihasilkan bisa memenuhi tujuan yang diharapkan, atau dengan kata lain anggaran digunakan secara tepat (spending wisely). Value for money menghendaki organisasi sektor publik (pemerintah desa) dapat memenuhi prinsip ekonomi, efisiensi dan efektivitas tersebut secara bersama-sama yang berarti mampu menggunakan uang public (anggaran) secara hemat, cermat dan tepat untuk mencapai target, sasaran dan tujuan.

Tahapan penilaian efektivitas melalui evaluasi. Evaluasi bisa dilakukan pada pelaksanaan pendapatan. Menurut Ritonga (2014), mengevaluasi efektivitas pelaksanaan pendapatan daerah dalam dokumen evaluasi kinerja pelaksanaan pendapatan daerah dengan cara membandingkan jumlah realisasi penerimaan rincian obyek pendapatan dengan jumlah rencana rincian obyek pendapatan. Pelaksanaan pendapatan akan dinyatakan efektif jika hasilnya sama dengan atau lebih dari $100 \%$ atau tidak efektif jika hasilnya kurang dari $100 \%$.

\section{Struktur Anggaran Pendapatan dan Belanja Desa (APBDes)}

Anggaran Pendapatan dan Belanja Desa (APBDes) merupakan rencana keuangan tahunan desa. Menurut Permendagri Nomor 113 mengenai pengelolaan keuangan desa, struktur APBDes terdiri dari Pendapatan Desa; Belanja Desa; dan Pembiayaan Desa. Pendapatan Desa meliputi semua penerimaan uang melalui rekening desa yang merupakan hak desa dalam 1 (satu) tahun anggaran yang tidak perlu dibayar kembali oleh desa. Belanja desa meliputi semua pengeluaran dari rekening desa yang merupakan kewajiban desa dalam 1 (satu) tahun anggaran yang tidak akan diperoleh pembayarannya kembali oleh desa. Sedangkan Pembiayaan Desa 
meliputi semua penerimaan yang perlu dibayar kembali dan/atau pengeluaran yang akan diterima kembali, baik pada tahun anggaran yang bersangkutan maupun pada tahun-tahun anggaran berikutnya. Struktur rinci APBDes dikelompokan kedalam 3 kelompok yaitu: Pendapatan Asli Desa (PADesa), Belanja Desa dan Pembiayaan Desa.

\section{Perencanaan, Pelaksanaan dan Pertanggungjawaban Keuangan Desa}

Dalam mengelola keuangan desa, melalui siklus pengelolaan keuangan desa yang meliputi berbagai tahap dari mulai perencanaan, pelaksanaan sampai dengan pertanggungjawaban keuangan desa. Dalam tahap perencanaan dimulai dengan menyusun Rencana Kegiatan Pemerintah Desa (RKPDesa). RKP Desa ini disusun oleh pemerintah desa pada bulan Juli dan ditetapkan pada bulan September setiap tahunnya.

Kemudian dilanjutkan dengan proses penganggaran yang tertuang dalam Anggaran Pendapatan dan Belanja Desa (APBDes). Siklus selanjutnya adalah pelaksanaan keuangan desa yang meliputi penyusunan RAB ( Rencana Anggaran Biaya), pengadaan barang dan jasa, pengajuan surat perintah pembayaran dan pembayaran. Tahap terakhir yaitu pertanggungjawaban. Dalam tahapan ini LKPJ dipertanggungjawaban kepada Badan Perwakilan Desa (BPD).

\section{Organisasi Pengelola Keuangan Desa}

Dalam pelaksanaan anggaran diperlukan organisasi pengelola keuangan desa agar pengelolaan keuangan desa dapat transparan, akuntabel dan efektif. Dalam organisasi ini Kepala Desa adalah pemegang kekuasaan pengelolaan keuangan desa dan mewakili Pemerintah Desa dalam kepemilikan kekayaan milik desa yang dipisahkan. Selanjutnya Pemegang Kekuasaan Pengelolaan Keuangan Desa (PKPKD) adalah Kepala Desa atau sebutan nama lain yang karena jabatannya mempunyai kewenangan menyelenggarakan keseluruhan pengelolaan keuangan desa

Wewenang Kades selaku PKPKDesa adalah:

a. menetapkan kebijakan tentang pelaksanaan APB Desa;

b. menetapkan Pelaksana Teknis Pengelolaan Keuangan Desa (PTPKD);

c. menetapkan petugas yang melakukan pemungutan penerimaan desa;

d. menyetujui pengeluaran atas kegiatan yang ditetapkan dalam APB Desa; 
e. melakukan tindakan yang mengakibatkan pengeluaran atas beban APB Desa barang dan jasa, dan belanja modal.

\section{Pengukuran Kinerja Keuangan Desa}

Salah satu cara yang digunakan untuk pengukuran kinerja keuangan desa adalah dengan menilai laporan keuangan desa. Menurut Mahmudi (2011), salah satu tujuan dan manfaat laporan keuangan adalah memberikan informasi keuangan sebagai pertimbangan pembuatan keputusan serta untuk pengukuran dan evalasi kinerja. Pengukuran dan evaluasi kinerja keuangan dapat dilakukan dengan memanfaatkan data dan informasi dalam laporan keuangan yang dipublikasikan. Laporan keuangan yang dipublikasikan bersifat umum (general purposive financial statements) bukan untuk memenuhi kebutuhan spesifik kalangan tertentu saja. Salah satu cara yang digunakan untuk menganalisis laporan keuangan adalah dengan analisis pertumbuhan. Analisis pertumbuhan dilakukan untuk mengetahui kinerja keuangan serta kecenderuangan baik berupa kenaikan atau penurunan kineja selama kurun waktu tertentu. Adapun cara menghitung pertumbuhan adalah sebagai berikut:

Pertumbuhan $\mathrm{X}_{\mathrm{t}}=\underline{\mathrm{X}_{\mathrm{t}}-\mathrm{X}_{\mathrm{t}-1}} \times 100 \%$

$$
\mathrm{X}_{\mathrm{t}-1}
$$

$\mathrm{X}_{\mathrm{t}}=$ Data variable $\mathrm{X}$ pada tahun $\mathrm{t}$

$\mathrm{X}_{\mathrm{t}-1}=$ Data variable $\mathrm{X}$ pada tahun $\mathrm{t}-1$

Laporan keuangan yang ada di desa dapat berupa laporan realisasi APBDes dan neraca desa.

\section{Penelitian Terdahulu}

Penelitian yang akan dilakukan ini merujuk pada beberapa penelitian terdahulu. Hasil penelitian Taufik (2013) menyimpulkan bahwa ruang lingkup pengelolaan keuangan desa meliputi kekayaan desa yang dikelola langsung oleh pemerintah desa, yaitu APBDesa. Dalam pengelolaan keuangan desa tersebut perlu diperhatikan dan ditaati asas umum pengelolaan keuangan desa yaitu, keuangan desa harus dikelola secara tertib, taat pada peraturan perundang-undangan, transparan, akuntabel, dan partisipatif dengan memperhatikan asas keadilan, kepatutan dan manfaat untuk masyarakat desa. Kemudian pengelolaan keuangan desa dilaksanakan 
dalam suatu sistem yang terintegrasi yang diwujudkan dalam APBDesa yang setiap tahun ditetapkan dengan peraturan desa.

Penelitian lain oleh Amerieska (2015) menyebutkan bahwa dalam pengelolaan keuangan dan aset desa ternyata masih terdapat superiortas akuntabilitas yang berpusat pada manusia, hal ini dilihat dari tingkatan akuntabilitas yang mana tingkatan pertama ditujukan pada dewan pengawas (BPD, Badan Permusyawaratan Desa). Tingkatan kedua, akuntabilitas manajemen diarahkan pada pemerintah kabupaten. Sedangkan pada tingkatan tiga, akuntabilitas manajemen berupa pertangungjawaban kepada Tuhan. Kemudian program-program yang dijalankan pada aktivitas pengelolaan keuangan dan aset desa masih mengedepankan program yang bersifat kebutuhan ekonomi dan sosial (akuntabilitas ekonomi dan akuntabilitas sosial).

Kemudian penelitian selanjutnya oleh Sutiyono (2009). Penelitian mengenai efektivitas pengelolaan keuangan di Desa Seling. Hasil penelitian menunjukkan bahwa efektivitas pengelolaan keuangan Desa di Desa Seling tahun 2007-2008 telah berjalan dengan baik hal ini dibuktikan dari terlaksananya proses perencanaan dan penyusunan anggaran desa melalui musbangdes, tersusunnya RAPDes dan ditetapkan menjadi APBDes tahun 2007-2008. Efektivitas pengelolaan tata usaha keuangan desa melalui pencatatan bukti penerimaan dan pengeluaran keuangan desa belum efektif khususnya dalam pencatatan dan pembukuan pemungutan pologoro desa .Pengawasan pengelolaan keuangan desa yang dilakukan di Desa Seling bertumpu pada pembacaan laporan yang dibuat setiap tiga bulan sekali. Sistem penilaian secara periodik pada tiga bulan sekali ini dilaporkan kepada BPD selaku wakil masyarakat dan juga pihak kecamatan selaku pimpinan. Sistem pengawasan secara periodik ini ditujukan untuk mengeleminir penyimpangan APBDes. Efektivitas pengelolaan keuangan desa di Desa Seling banyak dipengaruhi oleh faktor kepemimpinan dari Kepala Desa.

\section{METODE PENELITIAN}

\section{Waktu dan Lokasi Penelitian}

Waktu penelitian ini selama enam bulan terhitung mulai dari penandatangan kontrak penelitian dengan LPPMPMP Universitas Tidar pada bulan April 2018 sampai dengan 30 September 2018. Lokasi penelitian ini akan dilaksanakan di Pemerintah Desa Purwodadi Kecamatan Tegalrejo Kabupaten Magelang sebagai 
tempat pengambilan data. Dan di Universitas Tidar sebagai tempat pengolahan data dan pelaporan penelitian.

\section{Jenis Penelitian dan Fokus Penelitian}

Jenis penelitian ini adalah penelitian kuantitaif. Menurut Sugiyono (2009), dalam metode penelitian ini sebagai metode ilmiah/scientific karena telah memenuhi kaidah-kaidah ilmiah yaitu konkrit/empiris, obyektif, terukur, rasional dan sistematis. Dalam metode ini data penelitian dapat berupa angka-angka dan analisis menggunakan statistik. Fokus penelitian ini adalah pengelolaan keuangan di Desa Purwodadi yang meliputi aspek: efektivitas, mekanisme pengelolaan, perkembangan kinerja keuangan dan upaya-upaya yang dilakukan untuk mengatasi kendala-kendala dalam pengelolaan keuangan desa.

\section{Sumber Data Penelitian}

Data yang digunakan dalam penelitian ini merupakan data primer. Data primer adalah data yang diperoleh dari responden melalui kuisioner, kelompok fokus, dan panel, atau juga data hasil wawancara peneliti dengan narasumber (Sujarweni, 2015:89). Dalam penelitian ini data primer yang dimaksud adalah data yang diperoleh berdasarkan hasil wawancara dengan Kepala Desa, Perangkat Desa dan BPD. Data sekunder menurut Sugiono (2008:402) adalah sumber data yang tidak langsung memberikan data kepada pengumpul data. Data sekunder yang digunakan adalah yang didapat dari buku buku, jurnal-jurnal, yang berhubungan dengan penulisan tugas akhir ini. Karena data sekunder bersifat mendukung keperluan data primer. Data sekunder dengan menggunakan data time series yaitu periode tahun 2015-2017. Adapun data yang diperoleh yaitu berupa data profil desa dan laporan realisasi penerimaan Anggaran Pendapatan Belanja Desa (APBDes) dari Pemerintah Desa Purwodadi. Sumber data penelitian menurut Arikunto (2014) mendefinisikan bahwa sumber data adalah subjek dari mana data dapat diperoleh.

\section{Analisis Data}

Penelitian ini dilakukan pada Pemerintah Desa Purwodadi (tanpa sampel). Teknik analisis dalam penelitian menggunakan statistik deskriptif, yaitu: menyajikan data melalui tabel, grafik, rata -rata dan perhitungan persentase (Sugiyono, 2009). Selain itu juga menganalisis rasio efektivitas dan analisis pertumbuhan dalam mengukur kinerja keuangan desa yang ada di Desa Purwodadi. Kemudian setelah 
dilakukan analisis dengan menggunakan statistik deskriptif, dilakukan pengambilan kesimpulan dalam penelitian ini.

\section{HASIL DAN PEMBAHASAN}

\section{Gambaran Umum Desa}

Desa Purwodadi Kecamatan Tegalrejo Kabupaten Magelang merupakan desa yang bercorak agraris yang mempunyai luas wilayah sebesar 147,37 hektar. Luas wilayah tersebut terdiri dari luas tanah sawah sejumlah 95 hektar, luas tanah kering sebanyak 47,80 hektar dan tanah perkebunan sejumlah 4,57 hektar. Jumlah penduduk Desa Purwodadi sebanyak 1.708 orang (568 KK) yang terdiri dari: 891 orang laki-laki dan 817 orang perempuan. Dari jumlah tersebut sebanyak 538 orang laki-laki dan 496 orang perempuan yang termasuk dalam angkatan kerja dengan usia 18-56 tahun. Tingkat pendidikan yang dimiliki masyarakat Desa Purwodadi rata-rata tamatan SD, SLTP dan SLTA. Sedangkan mata pencaharian pokok mayoritas masyarakat adalah petani, buruh tani, dan wiraswasta.

Lembaga ekonomi yang mendukung aktifitas ekonomi di Desa Purwodadi terdiri dari Badan Umum Milik Desa (Bumdes), warung serba ada dan beberapa UMKM. Unitunit ekonomi tersebut dapat menyerap banyak tenaga kerja yang berasal dari masyarakat setempat. Sedangkan lembaga pendidikan formal dan lembaga pendidikan formal keagamaan yang ada di Desa Purwodadi meliputi: satu TK, satu Sekolah Dasar (SD), satu sekolah Islam, satu Raudhatul Athfal, satu Ibtidayah dan satu pondok pesantren. Lembagalembaga tersebut ikut aktif dalam mendidik masyarakat.

\section{Efektifitas Pengelolaan Keuangan Desa}

Menurut Mahmudi (2011) Efektivitas merupakan perbandingan antara hasil yang diharapkan (target) dengan hasil yang sesungguhnya dicapai. Hasil atau target yang diharapkan merupakan outcame sedangkan hasil yang dicapai merupakan output. Efektivitas membandingkan antara outcome dengan output. Fokus efektivitas adalah outcame (hasil). Suatu organisasi, program atau kegiatan dinilai efektif apabila output yang dihasilkan bisa memenuhi tujuan yang diharapkan, atau dengan kata lain anggaran digunakan secara tepat (spending wisely).

Tahapan penilaian efektivitas melalui evaluasi. Evaluasi bisa dilakukan pada pelaksanaan pendapatan. Menurut Ritonga (2014), mengevaluasi efektivitas pelaksanaan pendapatan daerah dalam dokumen evaluasi kinerja pelaksanaan 
pendapatan daerah dengan cara membandingkan jumlah realisasi penerimaan rincian obyek pendapatan dengan jumlah rencana rincian obyek pendapatan. Pelaksanaan pendapatan akan dinyatakan efektif jika hasilnya sama dengan atau lebih dari $100 \%$ atau tidak efektif jika hasilnya kurang dari $100 \%$. Dalam penelitian ini menggunakan penilaian efektivitas pendapatan daerah untuk menilai efektivitas pengelolaan keuangan desa atau penerimaan pendapatan desa.

Tabel 1.

Efektifitas Pengelolaan Keuangan Desa Purwodadi Tahun 2015

\begin{tabular}{|c|c|c|c|c|}
\hline $\begin{array}{c}\text { Sumber Pendapatan } \\
\text { Desa }\end{array}$ & $\begin{array}{c}\text { Jumlah Anggaran } \\
\text { (Rp) }\end{array}$ & $\begin{array}{c}\text { Jumlah Realisasi } \\
\text { (Rp) }\end{array}$ & $\begin{array}{c}\text { Efektifitas } \\
(\%)\end{array}$ & Keterangan \\
\hline Pendapatan Asli Desa & 43.562.000 & 43.562.000 & $100 \%$ & Efektif \\
\hline 1. Hasil Usaha & 17.345 .000 & 17.345 .000 & $100 \%$ & Efektif \\
\hline 2. Hasil Aset & 0 & 0 & 0 & - \\
\hline $\begin{array}{l}\text { 3. Swadaya, Partisipasi } \\
\text { dan Gotong Royong }\end{array}$ & 26.217 .000 & 26.217 .000 & $100 \%$ & Efektif \\
\hline $\begin{array}{l}\text { 4. Lain-lain Pendapatan } \\
\text { Asli Desa }\end{array}$ & 0 & 0 & 0 & - \\
\hline Pendapatan Transfer & 524.312 .900 & 524.312 .900 & $100 \%$ & Efektif \\
\hline 1. Dana Desa & 261.522 .000 & 261.522 .000 & $100 \%$ & Efektif \\
\hline $\begin{array}{l}\text { 2. } \\
\text { pagian dari hasil } \\
\text { daerah retribusi } \\
\text { kabupaten/kota }\end{array}$ & 22.472 .000 & 22.472 .000 & $100 \%$ & Efektif \\
\hline 3. Alokasi Dana Desa & 192.132 .000 & 192.132 .000 & $100 \%$ & Efektif \\
\hline 4. Bantuan Propinsi & 40.000 .000 & 40.000 .000 & $100 \%$ & Efektif \\
\hline 5. Bantuan Kabupaten & 8.186 .900 & 8.186 .900 & $100 \%$ & Efektif \\
\hline Pendapatan Lain-Lain & 2.255 .700 & 1.750 .000 & $\mathbf{7 7 , 5 \%}$ & $\begin{array}{l}\text { Tidak } \\
\text { Efektif }\end{array}$ \\
\hline $\begin{array}{l}\text { 1. Hibah dan } \\
\text { sumbangan dari } \\
\text { Pihak ke-3 yang tidal } \\
\text { mengikat }\end{array}$ & 0 & 0 & 0 & - \\
\hline $\begin{array}{l}\text { 2. Lain-lain pendapatan } \\
\text { desa yang sah }\end{array}$ & 2.255 .700 & 1.750 .000 & $77,5 \%$ & Tidak Efekti \\
\hline
\end{tabular}

Sumber: APBDes Pemerintah Desa Purwodadi Tahun 2015

Berdasarkan tabel 1 diatas dinyatakan bahwa hampir semua sumber penerimaan pendapatan desa dalam APBDes Tahun 2015 dinyatakan efektif kecuali pada pos pendapatan lain-lain, yang belum efektif karena target/rencana penerimaan pendapatan belum mampu dicapai 100\%. Pos ini menunjukkan efektifitas diangka 77,5\%. Pos pendapatan lain-lain desa yang sah ini terdiri dari pos: kompensasi PDAM, pengelolaan PBB desa dan lain-lain. 
Tabel 2.

Efektifitas Pengelolaan Keuangan Desa Purwodadi Tahun 2016

\begin{tabular}{|c|c|c|c|c|}
\hline Sumber Pendapatan Desa & $\begin{array}{c}\text { Jumlah Anggarar } \\
\text { (Rp) }\end{array}$ & $\begin{array}{c}\text { Jumlah Realisasi } \\
\text { (Rp) }\end{array}$ & $\begin{array}{c}\text { Efektifitas } \\
(\%)\end{array}$ & Keteranga \\
\hline Pendapatan Asli Desa & 45.285 .000 & 45.285.000 & $100 \%$ & Efektif \\
\hline 1. Hasil Usaha Desa & 17.345 .000 & 17.345 .000 & $100 \%$ & Efektif \\
\hline 2. $\quad$ Hasil Aset & 6.000 .000 & 6.000 .000 & $100 \%$ & Efektif \\
\hline $\begin{array}{l}\text { 3. Swadaya, Partisipasi } \\
\text { dan Gotong Royong }\end{array}$ & 21.940 .000 & 21.940 .000 & $100 \%$ & Efektif \\
\hline $\begin{array}{l}\text { 4. Lain-lain Pendapatan } \\
\text { Asli Desa }\end{array}$ & 0 & 0 & 0 & - \\
\hline Pendapatan Transfer & 848.307.000 & 848.307.000 & $100 \%$ & Efektif \\
\hline 1. Dana Desa & 591.438 .000 & 591.438 .000 & $100 \%$ & Efektif \\
\hline $\begin{array}{ll}\text { 2. } & \begin{array}{l}\text { Bagian dari hasil pajak } \\
\text { dan retribusi daerah } \\
\text { kabupaten/kota }\end{array} \\
\end{array}$ & 22.400 .000 & 22.400 .000 & $100 \%$ & Efektif \\
\hline 3. Alokasi Dana Desa & 229.469 .000 & 229.469 .000 & $100 \%$ & Efektif \\
\hline 4. $\quad$ Bantuan Propinsi & 5.000 .000 & 5.000 .000 & $100 \%$ & Efektif \\
\hline 5. Bantuan Kabupaten & 0 & 0 & 0 & Efektif \\
\hline Pendapatan Lain-Lain & 13.246.000 & 13.246.000 & $100 \%$ & Efektif \\
\hline $\begin{array}{l}\text { 1. Hibah dan sumbangan } \\
\text { dari Pihak ke-3 yang } \\
\text { tidak mengikat }\end{array}$ & 1.000 .000 & 1.000 .000 & $100 \%$ & Efektif \\
\hline $\begin{array}{l}\text { 2. Lain-lain pendapatan } \\
\text { desa yang sah }\end{array}$ & 12.246 .000 & 12.246 .000 & $100 \%$ & Efektif \\
\hline
\end{tabular}

Sumber: APBDes Pemerintah Desa Purwodadi Tahun 2016

Berdasarkan tabel 2 diatas dapat dilihat bahwa pengelolaan keuangan desa Tahun 2016 pada pos penerimaan pendapatan desa sudah efektif karena rasio antara realisasi pendapatan dengan rencana pendapatan menunjukkan angka $100 \%$. Hal ini bisa dilihat pada pos Pendapatan Asli Desa (PAD), pendapatan transfer dan pendapatan lain-lain.

Tabel 3.

Efektifitas Pengelolaan Keuangan Desa Purwodadi Tahun 2017

\begin{tabular}{|c|c|c|c|c|}
\hline $\begin{array}{c}\text { Sumber Pendapatan } \\
\text { Desa }\end{array}$ & $\begin{array}{c}\text { Jumlah Anggaran } \\
\text { (Rp) }\end{array}$ & $\begin{array}{c}\text { Jumlah Realisasi } \\
\text { (Rp) }\end{array}$ & $\begin{array}{c}\text { Efektifitas } \\
(\%)\end{array}$ & Keterangan \\
\hline Pendapatan Asli Desa & 42.785.000 & 40.785 .000 & $95 \%$ & $\begin{array}{l}\text { Tidak } \\
\text { Efektif }\end{array}$ \\
\hline 1. Hasil Usaha Desa & 17.345 .000 & 17.345 .000 & $100 \%$ & Efektif \\
\hline 2. Hasil Aset & 0 & 0 & 0 & - \\
\hline $\begin{array}{l}\text { 3. } \begin{array}{r}\text { Swadaya, Partisipasi } \\
\text { dan Gotong Royong }\end{array} \\
\end{array}$ & 25.440 .000 & 23.440 .000 & $92,13 \%$ & Efektif \\
\hline $\begin{array}{l}\text { 4. Lain-lain Pendapatar } \\
\text { Asli Desa }\end{array}$ & 0 & 0 & 0 & - \\
\hline Pendapatan Transfer & 1.161.338.000 & 1.161.338.000 & $100 \%$ & Efektif \\
\hline 1. Dana Desa & 753.082 .000 & 753.082 .000 & $100 \%$ & Efektif \\
\hline $\begin{array}{ll}\text { 2. } & \text { Bagian dari hasil } \\
& \text { pajak dan retribusi } \\
& \text { daerah } \\
& \text { kabupaten/kota }\end{array}$ & 25.255 .000 & 25.255 .000 & $100 \%$ & Efektif \\
\hline 3. Alokasi Dana Desa & 248.001 .000 & 248.001 .000 & $100 \%$ & Efektif \\
\hline 4. Bantuan Keuangan & 135.000 .000 & 135.000 .000 & $100 \%$ & Efektif \\
\hline
\end{tabular}




\begin{tabular}{|c|c|c|c|c|}
\hline Pendapatan Lain-Lain & 15.391 .500 & 7.205 .500 & $46,8 \%$ & $\begin{array}{l}\text { Tidak } \\
\text { Efektif }\end{array}$ \\
\hline $\begin{array}{ll}\text { 1. } & \text { Hibah dan } \\
\text { sumbangan dari } \\
\text { Pihak ke-3 yang } \\
\text { tidak mengikat }\end{array}$ & 0 & 0 & 0 & - \\
\hline $\begin{array}{ll}2 . & \begin{array}{l}\text { Lain-lain pendapatan } \\
\text { desa yang sah }\end{array}\end{array}$ & 15.391 .500 & 7.205 .500 & $46,8 \%$ & Tidak Efekti \\
\hline
\end{tabular}

Sumber: APBDes Pemerintah Desa Purwodadi Tahun 2017

Berdasarkan tabel 3 diatas dinyatakan bahwa pada pengelolaan keuangan desa sumber pendapatan desa terdapat dua pos pendapatan yang belum efektif yaitu: Pos pendapatan asli desa sebesar $95 \%$ dan pos pendapatan lain-lain sebesar 46,8\%. Pada pos pendapatan asli desa tidak efektif berasal dari pos swadaya, partisipasi dan gotong royong sebesar 92,13\%. Sedangkan realisasi pada pos pendapatan lain-lain desa yang sah ini, terdapat satu pos yang belum mampu memenuhi target penerimaan yaitu: pos kompensasi PDAM yang ditargetkan Rp 8.186.000,00 tetapi belum dapat terealisasi.

\section{Perkembangan Kinerja Keuangan Desa}

Perkembangan kinerja keuangan Desa Purwodadi dapat dilihat dari aspek realisasi pendapatan desa

Tabel 4.

Perkembangan Realisasi Pendapatan Desa Purwodadi Tahun 2015-2016

\begin{tabular}{|c|c|c|c|c|}
\hline $\begin{array}{c}\text { Sumber Pendapatan } \\
\text { Desa }\end{array}$ & \begin{tabular}{c|} 
Jumlah \\
Realisasi (Rp) \\
Th 2015 \\
\end{tabular} & \begin{tabular}{c|} 
Jumlah \\
Realisasi (Rp) \\
Th 2016 \\
\end{tabular} & Selisih (Rp) & $\begin{array}{c}\text { Pertumbuhan } \\
(\%)\end{array}$ \\
\hline Pendapatan Asli Desa & 43.562 .000 & 45.285 .000 & 1.723 .000 & $3,95 \%$ \\
\hline 1. Hasil Usaha & 17.345 .000 & 17.345 .000 & 0 & 0 \\
\hline 2. Hasil Aset & 0 & 6.000 .000 & 6.000 .000 & $13,77 \%$ \\
\hline $\begin{array}{ll}\text { 3. } & \text { Swadaya, Partisipasi } \\
\text { dan Gotong Royong }\end{array}$ & 26.217 .000 & 21.940 .000 & $(4.277 .000)$ & $(9,81 \%)$ \\
\hline $\begin{array}{l}\text { 4. Lain-lain Pendapatan } \\
\text { Asli Desa }\end{array}$ & 0 & 0 & 0 & 0 \\
\hline Pendapatan Transfer & 524.312 .900 & 848.307.000 & 323.994.100 & $61,8 \%$ \\
\hline 1. Dana Desa & 261.522 .000 & 591.438 .000 & 329.916 .000 & $62,9 \%$ \\
\hline 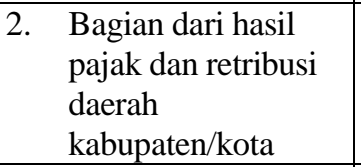 & 22.472 .000 & 22.400 .000 & $(72.000)$ & $(0,01 \%)$ \\
\hline 3. Alokasi Dana Desa & 192.132 .000 & 229.469 .000 & 37.337 .000 & $7,12 \%$ \\
\hline 4. $\quad$ Bantuan Propinsi & 40.000 .000 & 5.000 .000 & $(35.000 .000)$ & $(6,67 \%$ \\
\hline 5. Bantuan Kabupaten & 8.186 .900 & 0 & $(8.186 .900)$ & $(1,56 \%)$ \\
\hline Pendapatan Lain-Lain & 1.750 .000 & 13.246.000 & 11.496 .000 & $656,9 \%$ \\
\hline $\begin{array}{ll}\text { 1. } & \text { Hibah dan } \\
\text { sumbangan dari } \\
\text { Pihak ke-3 yang tidah } \\
\text { mengikat }\end{array}$ & 0 & 1.000 .000 & 1.000 .000 & $57,1 \%$ \\
\hline $\begin{array}{l}\text { 2. Lain-lain pendapatan } \\
\text { desa yang sah }\end{array}$ & 1.750 .000 & 12.246 .000 & 10.496 .000 & $599,7 \%$ \\
\hline
\end{tabular}


Tabel 5.

Perkembangan Realisasi Pendapatan Desa Purwodadi Tahun 2016-2017

\begin{tabular}{|c|c|c|c|c|}
\hline $\begin{array}{c}\text { Sumber Pendapatan } \\
\text { Desa }\end{array}$ & \begin{tabular}{c|} 
Jumlah \\
Realisasi (Rp) \\
Th 2016
\end{tabular} & $\begin{array}{c}\text { Jumlah Realisas } \\
\text { (Rp) } \\
\text { Th 2017 }\end{array}$ & Selisih (Rp) & $\begin{array}{c}\text { Pertumbuhan } \\
(\%)\end{array}$ \\
\hline Pendapatan Asli Desa & 45.285.000 & 40.785.000 & $(4.500 .000)$ & $(9,93 \%)$ \\
\hline 1. Hasil Usaha & 17.345 .000 & 17.345 .000 & 0 & 0 \\
\hline 2. Hasil Aset & 6.000 .000 & 0 & $(6.000 .000)$ & $(13,2 \%)$ \\
\hline $\begin{array}{l}\text { 3. Swadaya, Partisipasi } \\
\text { dan Gotong Royong }\end{array}$ & 21.940 .000 & 25.440 .000 & 3.500 .000 & $7,72 \%$ \\
\hline $\begin{array}{l}\text { 4. Lain-lain Pendapatan } \\
\text { Asli Desa }\end{array}$ & 0 & 0 & 0 & 0 \\
\hline Pendapatan Transfer & 848.307.000 & 1.161.338.000 & 313.031.000 & $36,9 \%$ \\
\hline 1. Dana Desa & 591.438 .000 & 753.082 .000 & 161.644 .000 & $19,05 \%$ \\
\hline $\begin{array}{l}\text { 2. } \\
\text { Bagian dari hasil } \\
\text { pajak dan retribusi } \\
\text { daerah } \\
\text { kabupaten/kota }\end{array}$ & 22.400 .000 & 25.255 .000 & 2.855 .000 & $0,33 \%$ \\
\hline 3. Alokasi Dana Desa & 229.469 .000 & 248.001 .000 & 18.532 .000 & $2,18 \%$ \\
\hline 4. Bantuan Keuangan & 5.000 .000 & 135.000 .000 & 130.000 .000 & $15,3 \%$ \\
\hline Pendapatan Lain-Lain & 13.246.000 & 7.205 .500 & $(6.040 .500)$ & $(45,5 \%)$ \\
\hline $\begin{array}{l}\text { 1. Hibah dan } \\
\text { sumbangan dari } \\
\text { Pihak ke-3 yang tidah } \\
\text { mengikat }\end{array}$ & 1.000 .000 & 0 & $(1.000 .000)$ & $(7,54 \%)$ \\
\hline $\begin{array}{l}\text { 2. Lain-lain pendapatan } \\
\text { desa yang sah }\end{array}$ & 12.246 .000 & 7.205 .500 & $(5.040 .500)$ & $(38,0 \%)$ \\
\hline
\end{tabular}

Berdasarkan tabel 4 dan 5 diatas, dapat dilihat bahwa pendapatan asli desa mengalami peningkatan sebesar 3,95\% di tahun 2016 dan mengalami penurunan sebesar 9,93\% di tahun 2017. Realisasi pendapatan transfer meningkat di tahun 2016 sebesar 61,8\% dan 36, 9\% di tahun 2017. Kemudian dari realisasi pos pendapatan lain-lain juga mengalami peningkatan yang siginifikan di tahun 2016 sebesar 656,9\%. Sedangkan di tahun 2017 mengalami penurunan sebesar 45,5\%.

\section{Mekanisme Pengelolaan Keuangan Desa Purwodadi}

Mekanisme pengelolaan keuangan Desa Purwodadi dimulai dengan penyusunan Rencana Pembangunan Jangka Menengah Desa (RPJMDesa) yang berisi mengenai dokumen rencana pembangunan dan program-program pembangunan desa selama 6 tahun. Kemudian atas dasar RPJMDesa disusun Rencana Kerja Pemerintah Desa (RKP Desa). RKP Desa ini didasarkan pada hasil Musrenbangdes (Musyawarah Perencanaan Pembangunan Desa). Musrenbangdes ini juga mengacu hasil musyawarah dusun (Musdus). Kemudian berdasarkan RKP desa disusun rancangan peraturan desa tentang 
APBDesa. Dalam musrenbangdes yang dilakukan setiap tahun akan menetapkan hasil RKP Desa tahun sebelumnya menjadi APBdes tahun berjalan. Selain itu melalui musrenbangdes juga akan disusun RKP Desa tahun yang akan datang. Sebagai contoh: dalam musrenbangdes Tahun 2017 akan menetapkan hasil RKP Desa Tahun 2016 menjadi APBDes Tahun 2017. Kemudian juga akan disusun RKP Desa Tahun 2018. Selain itu dalam musrenbangdes tersebut juga akan melakukan evaluasi terhadap RKP Desa Tahun 2016.

Mekanisme pengelolaan keuangan Desa Purwodadi Tahun 2015-2017 mengacu Peraturan Bupati Magelang Nomor 50 Tahun 2015 tentang pedoman pengelolaan keuangan desa dan mengacu Permendagri No 113 Tahun 2014 tentang pengelolaan keuangan desa. Dalam pengelolaan keuangan desa di Desa Purwodadi meliputi tahap yaitu: tahap perencanaan, pelaksanaan, penatausahaan, pelaporan dan pertanggungjawaban.

\section{Upaya -Upaya Yang Dilakukan Dalam Mengatasi Kendala Pengelolaan Keuangan Desa}

Dalam melakukan pengelolaan keuangan desa yang efektif dalam mendukung transparansi dan akuntabilitas keuangan desa terdapat beberapa kendala atau hambatan. Berbagai upaya dilakukan untuk mengatasi kendala tersebut. Berdasarkan wawancara yang dilakukan terhadap Kepala Desa dan Sekretaris Desa Purwodadi, dalam pengelolaan keuangan desa terdapat beberapa kendala dan hambatan sebagai berikut:

1. Dalam tahap pelaksanaan program APBDes pencairan anggaran/dana dari kabupaten kadang terlambat masuk ke rekening desa

2. Mekanisme pelaporan APBDes harus kolektif di kecamatan, sehingga hal ini dapat menghambat program pembangunan desa yang lain. Karena desa yang tepat waktu dalam melaporkan APBDes akan menunggu desa-desa yang lain yang terlambat melaporkan.

3. Dalam perencanaan ABPDes kadang kala harus menunggu aturan yang berlaku seperti: peraturan bupati tentang pedoman penyusunan APBDes, padahal desa sudah siap menyusun APBDes.

4. Terbatasnya sumberdaya manusia yang mempunyai kompetensi di bidang pengelolaan keuangan desa 
Kemudian untuk mengatasi kendala dan hambatan tersebut dilakukan upaya-upaya, diantaranya adalah: mendorong badan legislatif/DPRD Kabupaten Magelang untuk segera mengesahkan Anggaran Pendapatan Belanja Daerah (APBD) Kabupaten Magelang dengan cara melakukan audiensi antara Paguyuban Kepala Desa Kabupaten Magelang dengan anggota DPRD untuk menyelesaikan masalah tersebut. Dengan segera di sahkannya APBD Kabupaten Magelang maka peraturan bupati mengenai pedoman penyusunan APBDes juga akan segera terbit yang akan dapat menjadi acuan bagi desa dalam menyusun APBDes. Sehingga APBDes segera dapat disusun. Kemudian untuk mengatasi keterbatasan dalam sumberdaya manusia yang mempunyai kompetensi dibidang pengelolaan keuangan desa, beberapa perangkat desa diikutsertakan pelatihan, workshop maupun seminar dibidang pengelolaan keuangan desa yang diselenggarakan oleh pemerintah daerah.

\section{Efektivitas Pengelolaan Keuangan Desa dari Aspek Penerimaan Pendapatan}

Efektivitas pengelolaan keuangan desa dapat diukur melalui perbandingan antara realisasi pendapatan dengan target/rencana pendapatan. Dalam laporan APBDesa Purwodadi Tahun 2015-2017 terdapat anggaran/rencana dan realisasi pendapatan. Ada tiga sumber pendapatan desa yaitu: Pendapatan Asli Desa (PAD), Pendapatan Transfer dan Pendapatan lain-lain. Rasio antara realisasi dengan target pendapatan dianggap efektif apabila sama atau lebih besar dari $100 \%$ dan dianggap tidak efektif kalo kurang dari $100 \%$.

Pada laporan realisasi APBDes Purwodadi tahun 2015 menunjukan angka rata-rata $100 \%$ pada pos Pendapatan Asli Desa (PAD) dan Pos pendapatan transfer. Angka ini dianggap efektif yang dapat diartikan bahwa target PAD dan Pendapatan transfer dapat terealisasi $100 \%$. Sedangkan pos pendapatan lain-lain menunjukkan angka efektivitas 77,5\%. Angka ini menunjukan bahwa pada pos pendapatan lain-lain belum efektif karena target penerimaan pendapatan lain-lain tidak dapat dicapai/hanya dicapai sebesar $77,5 \%$ dari rencana/target pendapatan. Sedangkan pada laporan realisasi APBDes Purwodadi Tahun 2016 menunjukkan bahwa pengelolaan keuangan desa dilihat dari sumber penerimaan pendapatan dinyatakan efektif karena semua pos penerimaan pendapatan yaitu: PAD, pendapatan transfer dan pendapatan lain-lain menunjukkan angka rasio $100 \%$ artinya bahwa target pendapatan dapat tercapai realisasinya. 
Kemudian berdasarkan laporan realisasi APBDesa Purwodadi Tahun 2017 pada tabel 3 menunjukan angka bahwa terdapat pos PAD hanya dapat direalisasikan sebesar 95\% dari target dan pos pendapatan laian-lain hanya mampu direalisasi sebesar 46,8\% dari target. Angka ini menunjukan bahwa dua pos tersebut belum efektif. Sedangkan pos pendapatan transfer menunjukan angka $100 \%$ yang berarti sudah dapat dicapai sesuai dengan target. Untuk dapat meningkatkan efektivitas tersebut perlu dilakukan langkah terutama pada pos pendapatan lain-lain dengan meningkatkan pendapatan kompensasi PDAM, pendapatan pengelolaan PBB dan lain-lain pendapatan desa yang sah. Selain itu perlu meningkatkan pos penerimaan pendapatan asli desa.

\section{Perkembangan Kinerja keuangan Desa Purwodadi Periode tahun 2015-2017}

Perkembangan kinerja keuangan Desa Purwodadi dapat dilihat dari aspek anggaran (target) pendapatan, realisasi pendapatan desa dan realisasi belanja desa. Berdasarkan tabel 4 dan tabel 5 dapat dilihat bahwa terdapat pertumbuhan anggaran pendapatan dari tahun 2015-2017. Jika dibandingkan dengan Tahun 2015-2016, pada pos pendapatan asli desa terdapat kenaikan 3,95\%, pada pos pendapatan transfer terdapat kenaikan sebesar $61,7 \%$. Dan pada pos pendapatan lain-lain naik sebesar 487,3\%. Kemudian jika dilihat perkembangan tahun 2016-2017 anggaran pendapatan desa juga mengalami pertumbuhan. Pada pos pendapatan gtransfer tumbuh sebesar 36,9\% dan pos pendapatan lain-lain tumbuh sebesar 16,19\%. Dan pada pos pendapatan asli desa justru mengalami penuruan sebesar 5,52\%. Pertumbuhan anggaran pendapatan desa ini mencerminkan bahwa Desa Purwodadi berupaya untuk meningkatkan program-program pembangunan melalui penetapan kenaikan target anggaran pendapatan desa.

Adapun jika dilihat dari aspek realisasi APBDes Purwodadi dari Tahun 2015-2017 juga mengalami pertumbuhan yang cukup signifikan. Berdasarkan tabel 4 dan tabel 5 dapat dilihat perkembangan realisasi pendapatan desa Purwodadi. Berdasarkan laporan realisasi APBDes Purwodadi Tahun 2015-2016 terdapat kenaikan pada pos PAD sejumlah $3,95 \%$. Sementara dilihat dari pos pendapatan transfer tumbuh sebesar $61,8 \%$ dan dari pos pendapatan lain-lain tumbuh sangat signifikan sebesar 656,9\%. Kemudian jika dilihat perkembangan dari Tahun 2016-2017 juga sama, beberapa pos pendapatan desa mengalami pertumbuhan yang signifikan. Total penerimaan pada tahun 2016 sebesar Rp 906.838.000 naik menjadi Rp 1.209.328.500. Dilihat dari pos pendapatan transfer tumbuh sebesar 36,9\%. Dari tahun 2015-2017 terdapat kenaikan persentase realisasi pendapatan 
transfer dari 61,8\% di tahun 2016 dan 36,9\% di tahun 2017. Hal ini terjadi karena adanya penambahan sumber penerimaan dari dana desa. Pertumbuhan yang signifikan dari dana desa ini harus dimanfaatkan secara maksimal oleh Desa Purwodadi dalam menyelenggarakan program-program pembangunan yang secara langsung dapat meingkatkan kesejahteraan masyarakat.

\section{Mekanisme Pengelolaan Keuangan Desa Purwodadi}

Terdapat empat tahap dalam pengelolaan keuangan desa yaitu: tahap perencanaan, tahap pelaksanaan, tahap penatausahaan dan pelaporan serta tahap pertanggungjawaban. Dalam tahap perencanaan dibutuhkan sinergitas dan kerjasama dari seluruh komponen masyarakat. RPJMDesa berisi rencana pembangunan jangka menengah desa selama 6 tahun yang akan dibuat acuan dalam menyusun RKP Desa Purwodadi. Sedangkan RKP Desa dibuat dengan mendengarkan masukan dan saran dari hasil musrenbangdes. Kemudian berdasarkan hasil musrenbangdes dibuat rancangan peraturan APBDesa. Rancangan peraturan APBDes ini akan diajukan oleh Kepala Desa bersama dengan BPD kepada Bupati/Walikota untuk mendapatkan pengesahan. Jika sudah mendapatkan evaluasi maka rancangan peraturan desa tentang APBDes tersebut akan menjadi peraturan desa mengenai APBDes. Dalam merencanakan dan menyusun APBDes juga harus selalu mengacu pada peraturan bupati mengenai pedoman penyusunan anggaran pendapatan dan belanja desa. Sebagai contoh: penyusunan APBDes Tahun 2017 menggunakan Peraturan Bupati Magelang Nomor 10 Tahun 2017 tentang pedoman penyusunan Anggaran Pendapatan dan Belanja Desa Tahun ANggaran 2017.

Kemudian dalam tahap pelaksanaan peraturan desa mengenai APBDes ini akan dijalankan oleh Kepala Desa. Berbagai program dan kegiatan pembangunan akan dijalankan dengan mengacu yang sudah dirinci dalam APBDes. Dalam tahap penatausahaan pengelolaan keuangan desa dilakukan oleh bendahara desa dan melaporkan kepada Kepala Desa. Kemudian Kepala Desa akan membuat laporan pertanggungjawaban realisasi pelaksanaan APBDes kepada Bupati/Walikota setiap semester. Dan dalam tahap pertanggungjawaban, Kepala Desa akan melaporkan laporan realisasi pelaksanaan APBDes kepada bupati/walikota setiap akhir tahun. Dalam berbagai tahapan pengelolaan keuangan desa harus adanya kerjasama dan koordinasi yang matang antara berbagai pihak baik dari Pemerintah Desa Purwodadi maupun dari Bupati Kabupaten Magelang, Sehingga dalam pelaksanaan APBDes dapat berjalan sesuai dengan target yang telah ditetapkan. 


\section{Upaya-Upaya Yang Dilakukan Dalam Mengatasi Kendala Pengeloalaan Keuangan Desa}

Beberapa hambatan atau kendala dalam pengelolaan keuangan desa Purwodadi dintaranya adalah mekanisme pelaporan APBDes harus kolektif di kecamatan, sehingga hal ini dapat menghambat program pembangunan desa yang lain. Karena desa yang tepat waktu dalam melaporkan APBDes akan menunggu desa-desa yang lain yang terlambat melaporkan. Hambatan /kendala ini juga sejalan dengan penelitian Anwar dan Jatmiko (2014) yang menyebutkan bahwa permasalahan dalam pengelolaan keuangan desa diantaranya adalah laporan Anggaran dan Belanja Desa (APBDes) yang di buat tiap-tiap desa masih bersifat konvensional (tradisional) dan sering terlambat dalam pengiriman ke kecamatan dan bahkan ke kabupaten. Hasil penelitian menunjukkan bahwa dari kuesioner yang disebarkan pada 5 desa, hanya 2 desa yang mempunyai pemahaman yang baik terhadap laporan keuangan. Hal ini menunjukkan bahwa banyak desa yang belum emmahami dengan baik mengenai laporan keuangan desa sehingga hal ini yang menyebabkan banyak desa terlambat dalam mengirimkan laporan ke kecamatan bahkan ke kabupaten.

Kemudian kendala yang lain mengenai terbatasnya sumberdaya manusia yang mempunyai kompetensi di bidang pengelolaan keuangan desa. Hal ini juga sejalan dengan hasil penelitian dari Adi (2013) menyebutkan bahwa dalam pengelolaan dan penatausahaan keuangan desa Mulawarman terdapat hambatan yang dirasakan Pemerintah Desa Mulawarman yang sangat terasa adalah tidak adanya tenaga ahli dalam pengelolaan dan penatausahaan keuangan desa, atau dalam kata lain perangkat desa kurang berkompeten dan perlu adanya pelatihan.

\section{SIMPULAN DAN SARAN}

\section{Simpulan}

1. Efektifitas pengelolaan keuangan Desa Purwodadi pada laporan realisasi APBDes Tahun 2015-2017 menunjukkan angka rata-rata 100\% yang berarti efektif. Hanya ada beberapa pos di Tahun 2015 yaitu: pos Realisasi Pendapatan lain-lain sebesar 77,5\% dan di Tahun 2017 pada pos realisasi Pendapatan Asli Desa (PAD) sebesar 
95\% dan pos realisasi pendapatan lain-lain sebesar 46,8\%. Kedua pos tersebut dikatakan tidak efektif karena realisasi dibawah $100 \%$.

2. Perkembangan kinerja keuangan Desa Purwodadi dilihat dari laporan realisasi APBDesa Tahun 2015-2017 selalu mengalami peningkatan

3. Mekanisme pengelolaan keuangan Desa Purwodadi berdasarkan pada Permendgari Nomor 113 Tahun 2014 yang meliputi beberapa tahap yaitu: perencanaan, pelaksanaan, penatausahaan dan pelaporan serta pertanggugjawaban.

4. Upaya-upaya yang dilakukan untuk mengatasi hambatan/kendala dalam pengelolaan keuangan desa yaitu: mendorong legislative/DPRD melalui paguyuban kepala desa untuk segera mengesahkan APBD Kabupaten Magelang, sehingga Peraturan Bupati mengenai pedoman penyusunan APBDes dapat segera terbit yang digunakan sebagai acuan bagi desa dalam menyusun APBDes. Kemudian dalam mengatasi kendala terbatasnya sumberdaya manusia yang mempunyai kompetensi di bidang pengelolaan keuangan desa dengan cara mengikutsertakan dalam pelatihan, workshop maupun seminar dibidang pengelolaan keuangan desa.

\section{Saran}

1. Pemerintah Desa Purwodadi meningkatkan upaya-upaya untuk mencapai realisasi APBDes terutama pada pos pendapatan lain-lain.

2. Dalam penelitian yang akan datang mengkaji secara khusus pengelolaan keuangan desa dari aspek pengeluaran dan pembiayaan APBDes Purwodadi

\section{DAFTAR PUSTAKA}

Adi, Hendro Pujo Sasongko. 2013. Implementasi pengelolaan dan penatausahaan keuangan desa berdasarkan perda no 16 tahun 2007 tentang keuangan desa di desa mulawarman kecamatan tenggarong seberang kabupaten kutai kartanegara. Jurnal Ilmu Pemerintahan Unmul. ejournal.ip.fisip.unmul. didownload tanggal 9 Agustus 2018

Amerieska, Siti. 2015. "Pengembangan Model Akuntabilitas Pengelolaan Keuangan dan Aset Desa Berbasis Shariate Enterprise Theory", Syariah Accounting Paper FEB UMS.

Anwar, Misbahul dan Jatmiko, Bambang. 2014. Kontribusi dan Peran Pengelolaan Keuangan Desa Untuk Mewujudkan Anggaran Pendapatan dan Belanja Desa Yang Transparan dan Akuntabel (Survey Pada Perangkat Desa Di Kecamatan Ngaglik Sleman Yogyakarta). Jurnal Akmenika UPY. Vol 11 No. 1. Web: 
http://upy.ac.id/ojs/index.php/akm/issue/view/34 Didownload Tanggal 9 Agustus 2018

Arikunto, Suharsimi.2014. "Prosedur Peneltian", Jakarta:Bhineka Cipta

Harsoyo. 1977. Manajemen Kinerja:Persada, Jakarta

Mahmudi. 2011. Akuntansi Sektor Publik. Cetakan Pertama. UII Press. Yogyakarta.

Pemerintah Desa Purwodadi. 2016. Laporan Realisasi APBDes Purwodadi Kecamatan Tegalrejo Kabupaten Magelang Tahun 2015

Pemerintah Desa Purwodadi. 2017. Laporan Realisasi APBDes Purwodadi Kecamatan Tegalrejo Kabupaten Magelang Tahun 2016

Pemerintah Desa Purwodadi. 2018. Laporan Realisasi APBDes Purwodadi Kecamatan Tegalrejo Kabupaten Magelang Tahun 2017

Pemerintah Desa Purwodadi. 2017. Buku Profil Desa Purwodadi Kecamatan Tegalrejo Kabupaten Magelang Tahun 2016

Peraturan Bupati Magelang Nomor 50 Tahun 2015 Tentang Pedoman Pengelolaan Keuangan Desa

Peraturan Bupati Magelang Nomor 10 Tahun 2017 Tentang Pedoman Penyusunan APBDes Tahun Anggaran 2017

Peraturan Menteri Dalam Negeri Republik Indonesia Nomor 113 Tahun 2014 Tentang Pengelolaan Keuangan Desa

Ritonga, Irwan Taufiq (2014). "Analisis laporan Keuangan Pemda" Penerbit: Lembaga Kajian Majanemen daerah. Yogyakarta

Sugiyono, 2003, Statistika Untuk Peneltian. Cetakan kelima, Bandung: Alfabeta.

Sugiyono. 2009.Metodologi Penelitian Kuantitatif Kualitatif dan R\&D.Cetakan kedelapan. Bandung:Alfabeta

Sutiyono, 2009. Efektivitas Pengelolaan Keuangan Desa (Studi Kasus Desa Seling Kecamatan Karang Sambung Kabupaten Kebumen Tahun 2007-2008). Skripsi. Jurusan Ilmu Pemerintahan. FISIP. UMY Yogyakarta.

Undang-Undang No. 33 Tahun 2004 tentang Perimbangan Keuangan Antara Pemerintah Pusat dan Daerah.

Undang-Undang No. 6 Tahun 2014 tentang Desa

Wardoyo.1980.Kamus Besar Bahasa Indonesia, Balai Jakarta 